\title{
SUSTAINABLE PRACTICES THAT ALLOW THE RECYCLING OF SOLID WASTE AND WASTEWATER IN URBAN MARKET- GARDENING
}

\author{
Ma. Neftali Rojas-Valencia \\ Ma.Teresa Orta de Velásquez \\ Victor Franco \\ National Autonomous University of Mexico
}

\begin{abstract}
Mexico City generates almost 11,900 tons of solid waste per day; $50 \%$ of the waste is organic and $34 \%$ recyclable. As a consequence of the large amount of waste produced, the scarcity of potable water, the increase in wastewater generation, and the need in cities to satisfy the growing demand for healthy nutritious food, it has become essential to devise alternative methods that will contribute to satisfying one of the most basic of human needs: the need for food. This study proposes a safe method for the disinfection of wastewater destined for reuse in urban agriculture. It also discusses the year-round production of fresh vegetables in confined urban spaces, using sustainable practices that involve the recycling of waste whilst at the same time saving water.

To address the aforementioned problems, this study aimed to determine the efficiency of applying organoponic techniques to urban crops, using selected organic compounds and recyclable solid waste products, plus home-made organic fertilizers and treated wastewater. Three different methods of wastewater disinfection were tested: Ozone, APT, and a combination of both. The results obtained demonstrate that in addition to disinfecting the wastewater, Ozone contributes with oxygen and nutrients to the soil, thereby reducing the need for chemical fertilizers. Ozone also reduces the risk of infection by eliminating highly pathogenic micro-organisms, and increases the rate of plant growth. Great benefits can therefore be derived from employing these urban agriculture techniques because, in addition to putting to good use waste products that are generated by the ton, these techniques also produce quality food plants that are $100 \%$ organic.
\end{abstract}

\section{KEYWORDS}

Sustainable practices; Recycling solid, waste and wastewater.

\section{INTRODUCTION}

Agriculture is not normally one of our daily activities especially if we are town-dwellers, even though food production is directly related to agriculture, and we all know something about what agriculture involves. Current trends in today's society tend to distance us even further from producing our own food, but some agriculture programmes are now striving to reverse these trends in Modern Cities [1, 2]. 
It is a fact that all the world's cities produce huge amounts of solid waste, and that drinking water is becoming progressively scarcer whilst we continue generating ever more wastewater. Mexico City produces a daily total of 11,850 tons of municipal solid waste [3], comprising $50 \%$ organic residues and $34 \%$ recyclable wastes. The problem is, however, that we do not know how to make good use of it. Similarly, there seems to be little interest in the city to save water. After the People's Republic of China, Mexico is the world's second biggest user of wastewater in agricultural activities; and in Latin America, Mexico is the country with the greatest number of hectares irrigated with recycled but untreated wastewaters [4].

The CNA (Mexico's National Water Commission) estimates that over the whole country about 350,000 hectares are being irrigated with municipal wastewater, at a rate of about 160 $\mathrm{me} / \mathrm{second}$. Some of this municipal wastewater is mixed with industrial wastewater, some with surface waters, and some with well-water. The impact of this on health is reflected in the rise of gastro-intestinal diseases and acute respiratory infections $[4,5]$.

The purpose of this project, therefore, was two-fold. Firstly, it set out to test feasible methods for treating wastewater destined for reuse in agriculture. Secondly, it suggests a strategy for cultivating several different types of fresh vegetables in confined urban spaces such as terraces, roof-gardens, back-yards, balconies and small gardens, without the use of pesticides or chemical fertilizers but re-using waste products, and without affecting public health.

The study aimed therefore: a) to determine the efficiency of applying the techniques of organoponia to urban crop-growing, utilizing selected organic compounds and recyclable solid waste products, plus treated wastewater; and b) to compare the disinfection efficiency of 3 different methods of wastewater treatment: i) Ozone, ii) APT, and iii) APT+Ozone, in the irrigation of the plants being grown in the organoponic modules.

\section{MATERIALS AND METHODOLOGY}

The first step was to collect a) organic wastes such as: fallen leaves, fruit and vegetable waste, wooden crates, egg boxes and liquid organic fertilizer (prepared from urine), for use in the cultivation; and b) recyclable solid waste such as: plastic packaging materials, used tyres, and disposable soft-drinks cans and bottles, to serve as plant pots and watering cans.

A heavy-duty cutter was used to slice the side off a used tyre, leaving a ring which was then turned inside out. The tyre was then lined with waste plastic packaging material. The plant pot thus constructed was filled with compacted dead leaves and finely chopped fruit and vegetable waste, with a thin layer of soil sprinkled on top which covered the whole container to a depth of $25 \%$. Previously germinated seedlings were then transplanted into the containers, or, in the case of some vegetables such as radishes, the seed was sown directly into this prepared soil mixture.

Three different disinfection treatments were applied to the wastewater, plus two control experiments. The first treatment type involved the use of wastewater treated with Ozone (Oe)). A $5 \mathrm{~L}$ reactor was used to produce the Ozone, and a concentration of $36.8 \mathrm{mgO}_{3} / \mathrm{L}$ (flow 1 $\mathrm{L} / \mathrm{min}$ ) gas-phase Ozone was applied to the base of the reactor for a period of one hour. At $\mathrm{pH}$ 7 and a temperature of $23{ }^{\circ} \mathrm{C}$, the concentration of Ozone dissolved in the liquid phase averaged $7.36 \mathrm{mg} / \mathrm{L}$; the dissolved Ozone being measured using the indigo method [6]. 
The second treatment type was the Advanced Primary Treatment (APT). The APT test was simulated in a jar test (Phipps and Bird model 7790-400), using $150 \mathrm{mg} / \mathrm{L}$ of Hydrated Octadeca Aluminium Sulphate and $1 \mathrm{mg} / \mathrm{L}$ of anionic polymer Prosifloc 252, which were added under mixed conditions. A period of $10 \mathrm{~min}$. was then allowed for sedimentation.

The third treatment type was a combination of $\mathrm{APT}+\mathrm{O}_{3}$. Two comparative experiments were also set up. In one, the plants were watered with totally untreated raw wastewater, and in the other the plants were watered with drinking water, which was the control experiment.

Determination of the following physical-chemical parameters related to the disinfection process was made for all the treatment types: alkalinity $(\mathrm{pH})$, Biochemical Oxygen Demand $\left(\mathrm{BOD}_{5}\right)$, Chemical Oxygen Demand (COD), and organic Nitrogen.

To ascertain the micro-biological quality of the cultivated plants, tests were carried out to detect the presence of pathogenic agents such as: Giardia sp., Helminth eggs and the following bacteria: Vibrio cholerae, Salmonella typhi, and total and faecal coliforms. Each set of experimental conditions was tested in quintuplicate, and all the modules were irrigated for a period of 6 months.

To determine the possible toxicity of the treatment types, different dilutions of the raw and treated wastewaters $(50 \%, 75 \%, 100 \% \mathrm{v} / \mathrm{v})$ were prepared in aliquots of $20 \mathrm{~mL}$. The different dilutions were then poured onto $45 \mathrm{~mm}$. Millipore Pads that had previously been laid over Petri dishes measuring $60 \times 15 \mathrm{~mm}$, until the Millipore Pads were totally soaked through. Then 10 seeds per dish per concentration of each treatment type were sprinkled on each Millipore Pad, the seeds being arranged in 4 rows of 3 seeds per row. The same procedure was followed with the control sample, which simply used drinking water, making a total of 75 dishes in all. The dishes were then covered and placed in a humidified incubator set at $24^{\circ} \mathrm{C}$, for a period of 5 days.

The results were subjected to a Kruskal-Wallis test analysis.

Bio-tests were conducted on commercially viable, fast-growing crop plants such as: radishes (Raphanus sativus L.), tomatoes (Lycopersicum esculentum), spearmint (Mentha piperita), camomile (Matricaria recutita), Romaine lettuce (Lactuca sativa) and Chinese cabbage (Brassica rapa). Pest-control was maintained by sowing aromatic plants in the containers to act as a natural repellent.

\section{RESULTS AND DISCUSSION}

\subsection{Results of the toxicity study}

The percentage of seeds that germinated in each box is set out in the last column of Table 1 . On the fifth day, five seedlings were selected from the seeds that had germinated in each Petri dish, and their length was measured. An average length was calculated per dish, and these values are set out in the germination column of Table 1 . The statistical analysis was conducted on the basis of said germination percentages and average lengths. A statistical diagram (Figure 1) shows the average length of the five seedlings selected from each dish of each treatment type. 
Kalmar ECO-TECH '07

KALMAR, SWEDEN, November 26-28, 2007

Table 1. Average length of the seedlings.

\begin{tabular}{|c|c|c|c|c|c|c|c|c|c|c|c|}
\hline Number & Code & Treatment & Boxe & $\begin{array}{l}\text { Length } \\
(\mathrm{cm})\end{array}$ & $\begin{array}{c}\text { Germination } \\
(\%)\end{array}$ & Number & Code & Treatment & Boxe & $\begin{array}{l}\text { Length } \\
(\mathrm{cm})\end{array}$ & $\begin{array}{c}\text { Germination } \\
(\%)\end{array}$ \\
\hline 1 & 101 & 1 & 1 & 5.26 & 90 & 39 & 309 & 3 & 9 & 6 & 90 \\
\hline 2 & 102 & 1 & 2 & 5.4 & 70 & 40 & 310 & 3 & 10 & 5.14 & 80 \\
\hline 3 & 103 & 1 & 3 & 6.1 & 100 & 41 & 311 & 3 & 11 & 5.14 & 100 \\
\hline 4 & 104 & 1 & 4 & 6.66 & 80 & 42 & 312 & 3 & 12 & 4.92 & 80 \\
\hline 5 & 105 & 1 & 5 & 5.98 & 100 & 43 & 313 & 3 & 13 & 5.94 & 80 \\
\hline 6 & 106 & 1 & 6 & 5.98 & 90 & 44 & 314 & 3 & 14 & 5.88 & 80 \\
\hline 7 & 107 & 1 & 7 & 5.4 & 90 & 45 & 315 & 3 & 15 & 5.46 & 70 \\
\hline 8 & 108 & 1 & 8 & 5.74 & 100 & 46 & 401 & 4 & 1 & 5.56 & 80 \\
\hline 9 & 109 & 1 & 9 & 6.84 & 100 & 47 & 402 & 4 & 2 & 5.4 & 80 \\
\hline 10 & 110 & 1 & 10 & 6.94 & 90 & 48 & 403 & 4 & 3 & 5.04 & 80 \\
\hline 11 & 111 & 1 & 11 & 5.92 & 90 & 49 & 404 & 4 & 4 & 6.64 & 80 \\
\hline 12 & 112 & 1 & 12 & 6.7 & 90 & 50 & 405 & 4 & 5 & 4.3 & 70 \\
\hline 13 & 113 & 1 & 13 & 6 & 80 & 51 & 406 & 4 & 6 & 5.54 & 90 \\
\hline 14 & 114 & 1 & 14 & 5.3 & 100 & 52 & 407 & 4 & 7 & 5.88 & 70 \\
\hline 15 & 115 & 1 & 15 & 6 & 90 & 53 & 408 & 4 & 8 & 4.9 & 80 \\
\hline 16 & 201 & 2 & 1 & 7.2 & 90 & 54 & 409 & 4 & 9 & 5.46 & 90 \\
\hline 17 & 202 & 2 & 2 & 6.34 & 100 & 55 & 410 & 4 & 10 & 5.94 & 80 \\
\hline 18 & 203 & 2 & 3 & 5.54 & 100 & 56 & 411 & 4 & 11 & 4.5 & 80 \\
\hline 19 & 204 & 2 & 4 & 5.08 & 100 & 57 & 412 & 4 & 12 & 5.9 & 90 \\
\hline 20 & 205 & 2 & 5 & 6.86 & 100 & 58 & 413 & 4 & 13 & 6.12 & 80 \\
\hline 21 & 206 & 2 & 6 & 6.08 & 100 & 59 & 414 & 4 & 14 & 5.04 & 80 \\
\hline 22 & 207 & 2 & 7 & 6.6 & 100 & 60 & 415 & 4 & 15 & 5.78 & 80 \\
\hline 23 & 208 & 2 & 8 & 6.54 & 100 & 61 & 501 & 5 & 1 & 6.302 & 100 \\
\hline 24 & 209 & 2 & 9 & 5.9 & 70 & 62 & 502 & 5 & 2 & 6.16 & 90 \\
\hline 25 & 210 & 2 & 10 & 5.52 & 90 & 63 & 503 & 5 & 3 & 5.82 & 90 \\
\hline 26 & 211 & 2 & 11 & 5.86 & 90 & 64 & 504 & 5 & 4 & 6.12 & 100 \\
\hline 27 & 212 & 2 & 12 & 5.96 & 90 & 65 & 505 & 5 & 5 & 5.08 & 100 \\
\hline 28 & 213 & 2 & 13 & 5.44 & 100 & 66 & 506 & 5 & 6 & 5.56 & 100 \\
\hline 29 & 214 & 2 & 14 & 6.14 & 90 & 67 & 507 & 5 & 7 & 4.98 & 90 \\
\hline 30 & 215 & 2 & 15 & 5.18 & 100 & 68 & 508 & 5 & 8 & 6.2 & 100 \\
\hline 31 & 301 & 3 & 1 & 6.12 & 80 & 69 & 509 & 5 & 9 & 4.84 & 90 \\
\hline 32 & 302 & 3 & 2 & 4.1 & 80 & 70 & 510 & 5 & 10 & 5.58 & 100 \\
\hline 33 & 303 & 3 & 3 & 5.1 & 80 & 71 & 511 & 5 & 11 & 5.82 & 80 \\
\hline 34 & 304 & 3 & 4 & 5.42 & 90 & 72 & 512 & 5 & 12 & 4.92 & 70 \\
\hline 35 & 305 & 3 & 5 & 4.42 & 100 & 73 & 513 & 5 & 13 & 6.48 & 90 \\
\hline 36 & 306 & 3 & 6 & 6.06 & 90 & 74 & 514 & 5 & 14 & 6.9 & 90 \\
\hline 37 & 307 & 3 & 7 & 5.38 & 90 & 75 & 515 & 5 & 15 & 6.26 & 90 \\
\hline 38 & 308 & 3 & 8 & 5.8 & 90 & & & & & & \\
\hline
\end{tabular}




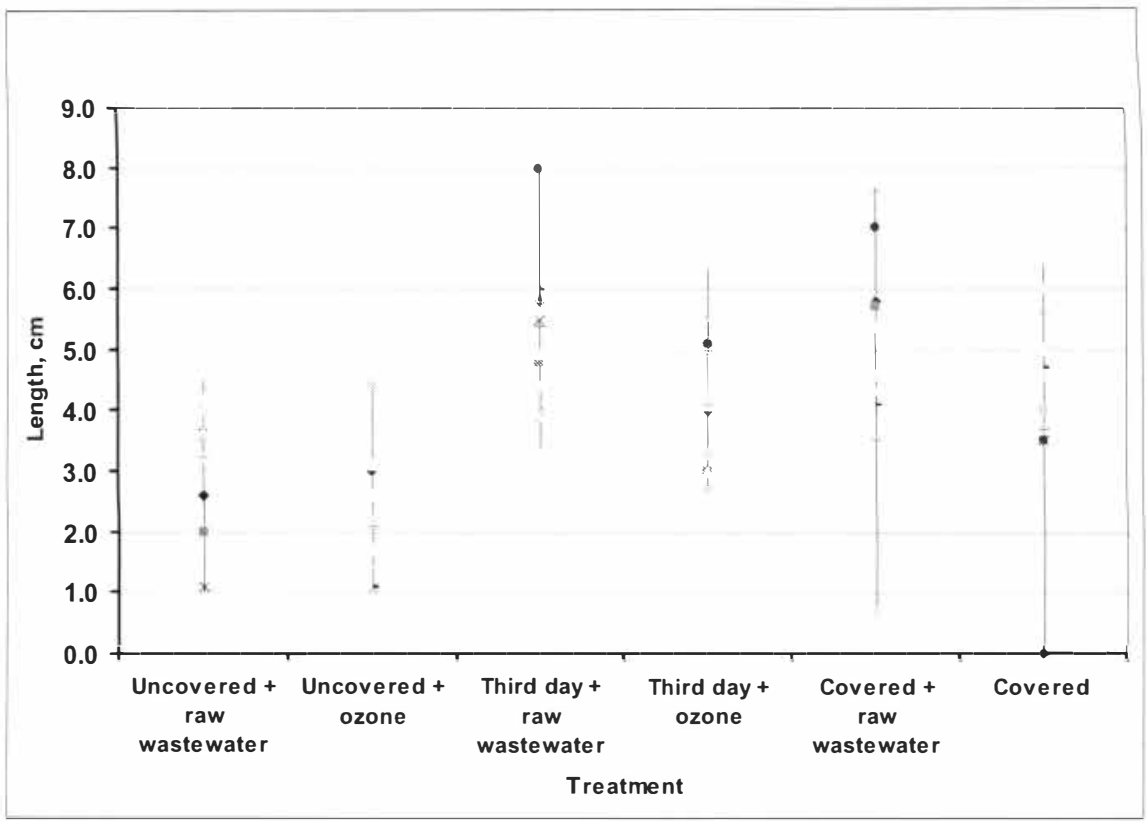

Figure 1. Range of germination length on the fifth day.

As can be seen in Table 2, the lettuce seedlings grew to a maximum average length when watered with APT-treated wastewater $(6.02 \mathrm{~cm}$.). This result is similar to the length obtained when watered with Ozone-treated wastewater $(6.01 \mathrm{~cm}$.). In other words, no significant difference was observed between these two treatments. The smallest average growth was observed in the seedlings irrigated with drinking water $(5.39 \mathrm{~cm}$.); and the next smallest average was seen in the seedlings irrigated with raw wastewater $(5.47 \mathrm{~cm}$.). If we remember that drinking water is free of plant nutrients, the result makes sense. In the case of raw wastewater, on the other hand, it may be due either to an excess of nutrients, or to the presence of some pollutant that inhibits growth. The standard deviation for the average length of the seedlings was approximately $0.6 \mathrm{~cm}$, regardless of the treatment applied.

Table 2. Average maximum length.

\begin{tabular}{|l|l|l|l|l|l|}
\hline Treatment & Boxes & $\begin{array}{l}\text { Half } \\
\text { statistic }\end{array}$ & $\begin{array}{l}\text { Standard } \\
\text { deviation }\end{array}$ & Minimun & Maxim \\
\hline Drinking water & 15 & 5.39 & 604 & 4.1 & 6.1 \\
Raw & 15 & 5.47 & 626 & 4.3 & 6.6 \\
wastewater & 15 & 5.80 & 628 & 4.8 & 6.9 \\
APT+Ozone & 15 & 6.02 & 614 & 5.1 & 7.2 \\
APT & 15 & 6.01 & 558 & 5.3 & 6.9 \\
Ozone & & & & & \\
\hline
\end{tabular}


The lowest germination percentages were observed in plants in the Petri dishes irrigated with raw wastewater and drinking water. In these cases, 10 of the 15 Petri dishes $(66.67 \%)$ irrigated with raw wastewater, and 7 of the 15 Petri dishes $(46.67 \%)$ treated with drinking water, gave a percentage of seeds germinated that was less than $80 \%$. By contrast, in the case of the rest of the treatments the percentage of germination was greater or equal to $90 \%$, in a total of $80 \%$ or more of the Petri dishes. In other words, in the Petri dishes irrigated with drinking water and raw wastewater, the median germination percentage was $80 \%$; in the Petri dishes irrigated with Ozone or with APT $+\mathrm{O}_{3}$ treatments, the median germination percentage was $90 \%$; and in the Petri dishes irrigated with APT-treated wastewaters, the median growth percentage was $100 \%$. According to the Kruskal-Wallis test, these medians are significantly different (test statistice $=24.156,4$ degrees of liberty, and level of significancee $=0.0001$ ).

According to the Variance Analysis Table (Table 3), there is a significant difference in the average length of seedlings irrigated with the different types of water (level of significance $=$ $0.0103, \mathrm{~F}=3.58$, with 4 and 70 degrees of liberty in the numerator and denominator respectively). Two treatments (Ozone and raw wastewater) were considered different because the absolute value of the difference between their measurements was greater than $0.44 \mathrm{~cm}$. Thus, it was calculated that the average length of the seedlings irrigated with drinking water and raw wastewater was similar (5.39 and $5.47 \mathrm{~cm}$. respectively), and that this was less than the length registered for the seedlings irrigated with Ozone and APT (6.01 and 6.02 respectively). The results for the combined $\mathrm{APT}+\mathrm{O}_{3}$ treatment fell between these two sets of extremes. Essentially, the average length of the seedlings irrigated with APT $+\mathrm{O}$ ( $(5.8 \mathrm{~cm}$.) did not differ significantly from the average lengths obtained for any of the rest of the treatments.

Table 3. Variance analysis.

\begin{tabular}{|l|l|l|l|l|l|}
\hline Source & SS & Df & MS & F & Prob > F \\
\hline Between groups & 5.26791108 & 4 & 1.31697777 & 3.58 & 0.0103 \\
Within groups & 25.7392779 & 70 & 0.36770397 & & \\
\hline Total & 31.007189 & 74 & 0.419016067 & & \\
\hline
\end{tabular}

\subsection{Results of the Multiple-Species Cultivation}

The growth of all the different types of plant used in the multiple-species cultivation, namely: lettuce (Lactuca sativa), radish (Raphanus sativus L.), spearmint (Mentha piperita), tomato (Lycopersicum esculentum), camomile (Matricaria recutita) and Chinese cabbage (Brassica rapa), evidenced good plant development with all the wastewater treatment types. However, the overall maximum growth was seen in the module irrigated with wastewater treated with $\mathrm{O}_{3}$ (see Table 4). 
Table 4. Growth register for the Multiple-Species Cultivation.

\begin{tabular}{|c|c|c|c|c|c|}
\hline \multirow{2}{*}{ Plant } & \multicolumn{5}{|c|}{ Treatment } \\
\cline { 2 - 6 } & $\begin{array}{c}\text { Raw } \\
\text { wastewater }\end{array}$ & Ozone & APT & APT+Ozone & $\begin{array}{c}\text { Drinking } \\
\text { water }\end{array}$ \\
\hline $\begin{array}{c}\text { Romaine lettuce } \\
(\mathrm{cm})\end{array}$ & 5 & 9 & 8 & 7 & 5 \\
\hline Tomatoes (cm) & 7 & 19 & 9 & 7 & 6 \\
\hline Radishes (cm) & 15 & 15 & 11 & 11 & 14 \\
\hline Spearmint (cm) & 16 & 18.5 & 16 & 13 & 17 \\
\hline Camomile (cm) & 17 & 26 & 23 & 15 & 16 \\
\hline $\begin{array}{c}\text { Chinese cabbage } \\
(\mathrm{cm})\end{array}$ & 39 & 48 & 46 & 43 & 32 \\
\hline $\begin{array}{c}\text { Chinese cabbage } \\
(\mathrm{gr})\end{array}$ & 705 & 1117 & 950 & 564 & 790 \\
\hline
\end{tabular}

The Chinese cabbage was the last plant to be harvested. The longest growth $(48 \mathrm{~cm}$.) and greatest weight $(1,117 \mathrm{~g})$ were observed in the plants irrigated with Ozone-treated wastewater. Conversely, the smallest average weight registered (564 g.) was seen in the cabbage irrigated with wastewater receiving the combined $\mathrm{APT}+\mathrm{O}_{3}$ treatment. A similar behaviour pattern was seen in the case of the other vegetables.

Smaller growth was observed in the crop plants irrigated with wastewater subjected to the combined $\mathrm{APT}+\mathrm{O}_{3}$ treatment compared to the crop plants irrigated with wastewater treated with Ozone alone or wastewater treated with APT alone.

As reported in previous studies [7], the fact that the combined APT $+\mathrm{O}_{3}$ treated wastewater produced smaller individual vegetables at harvest is due to the fact that there is an excess of nutrients in the soil, and an excess of nutrients far from helping actually inhibits general plant development. This finding is confirmed in other reports:[8] report that an excess of nutrients inhibits the growth of vegetables just as much as a lack of nutrients; [9] state that high concentrations of nutrients can reduce the yield at harvest; and [10] report that an excess of nitrogen can reduce the quality of lettuce and cause a crop to rot $[8,9,10]$.

By contrast, [11] report that the presence of Ozone in treated wastewater re-used in agricultural irrigation, can actually increase harvest vigour, reduce pests, reduce the need for chemical fertilizers, and improve the penetration of oxygen. It is worth noting that, theoretically, by oxygenating the soil, Ozone favours nitrification and the assimilation of nutrients. This coincides with the results of the research being reported in this paper [11].

The results of this study also show that wastewater treated with Ozone meets current Mexican Regulations with regard to the following micro-organisms: pathogenic agents such as Giardia sp. and Helminth eggs; plus the bacteria: Vibrio cholerae, Salmonella typhi, and total and faecal coliforms [12].

The concentrations of Nitrogen $(300 \mathrm{mg} / \mathrm{kg})$, Phosphorus $(100 \mathrm{mg} / \mathrm{kg})$ and Potassium (200 $\mathrm{mg} / \mathrm{kg}$ ) available in the soil met the demand required for crop plant cultivation, in the case of irrigation with wastewater treated with Ozone or APT. In this study the presence of nonnutrient metals was not detected in any case. Thus the wastewaters studied can be considered fit for reuse in agriculture. The presence of Zinc was detected at concentrations of $0.46,0.58$ 
and $1.26 \mathrm{mg} / \mathrm{L}$ in soil irrigated with wastewaters treated with $\mathrm{APT}, \mathrm{O}_{3}$ and $\mathrm{APT}+\mathrm{O}_{3}$ respectively. These concentrations favour crop cultivation because Zinc is vital for the formation of chlorophyll and growth hormones.

The best removal of $\mathrm{BOD}_{5}(93 \%)$ was achieved in wastewater treated with APT + Oẹ. Applying one hour of treatment with Ozone alone, at a rate of $7.36 \mathrm{mgO}_{3} / \mathrm{L}$, produced $88 \%$ removal; treatment by APT alone achieved $43 \%$ removal. In regard to COD, the best removal (also $93 \%$ ) was achieved in wastewater treated with Ozone alone. The application of APT $+\mathrm{O}_{3}$ produced $62 \%$ removal, and the application of APT alone produced $49 \%$ removal.

None of the plants died in any of the treatments.

\section{CONCLUSIONS}

The experimental conditions producing the best results were wastewater treated with Ozone, applying a rate of $7.36 \mathrm{mg} / \mathrm{L}$ at $\mathrm{pH} 7$ and a temperature of $238 \mathrm{C}$ for the period of one hour. Wastewaters thus treated meet current standards in Mexico for micro-organisms and heavy metals. Under these conditions, 15 minutes of ozonation resulted in $100 \%$ destruction of bacteria such as: $V$. cholerae, $S$. typhi and total and faecal coliforms; and one hour of ozonation produced total destruction of Helminth eggs and Giardia sp.

Wastewater treated with APT can be employed in agricultural irrigation, because it conserves the nutrients. However, although there is significant removal of faecal coliforms and other pathogenic micro-organisms, wastewaters thus treated do not meet Mexican Standard NOM001-ECOL-1996; Standard only being met after Ozone disinfection.

After six months' irrigation, no phytotoxic elements or metals were found that might have affected plant productivity or endangered public health as a result of consuming these plants.

The results obtained show that as well as disinfecting water, ozone also the growth of crop plants, thereby helping to reduce the need for chemical fertilizers. Thus the conclusion reached was that ozonation was the best treatment used in this project for wastewaters destined for reuse, and that ozonation reduces the risk to health present in food plants irrigated with totally untreated wastewater, especially when those foods are eaten raw.

Enormous advantages were noted in the practice of these urban agriculture techniques, because they lead to the selective recycling of waste materials that are generated by the ton, in the production of high quality $100 \%$ organic food, despite only having access to confined spaces.

More study and validation is required of the technique of putting solid wastes to good use in urban agriculture together with the reuse of treated wastewaters; and there is an urgent need to educate and encourage the general population in techniques of reuse and recycling.

This document provides guidelines and advice on the formulation and implementation of urban agriculture programmes that incorporate the use of wastewater plus the use of organic compounds and recyclable solid waste products.

\section{REFERENCES}

[1] Cervantes H., Juárez A., 2005. "Manual de Organoponia. Taller de agricultura". CICEANA, pp. 3 - 19. (In Spanish). 
[2] Terán Cabanillas Nancy, Agricultura Urbana tan novedosa como tradicional, CICEANA. (http://www.rebelion.org/otromundo/030930agriurbana.htm) (2003). (In Spanish).

[3] INEGI. Censo General de Población y Vivienda 2005 www.inegi.gob.mx. 2005. (In Spanish).

[4] Almanza Garza Victoriano. Reuso Agrícola de las aguas residuales de Cd. Juárez (Chih; México) en el Valle de Juárez y su impacto en la salud pública. Revista Salud Pública y Nutrición, pp.1-11. 2000 (In Spanish).

[5] Arreguín Cortés F., Moller Chávez G., Estrada Escalante V., Rivas Hernández A. El reuso del agua en México. Instituto Mexicano de Tecnología del Agua. 2005 (In Spanish).

[6] Bader, H., J. Hoigné. "Determination of Ozone by the Indigo Method" Wat. Res. 15 (4):449. 1981.

[7] Orta de Velásquez, M.T., Rojas-Valencia, M.N, Campos-Reales-Pineda, E. (2006) Evaluation of phytotoxic elements, trace elements and nutrients in a standardized crop plant, irrigated with raw wastewater treated by APT and ozone. Water Science \& Technology, 54 (11-12), 165-173.

[8] Huett, D.O., Dettmann, E. B. Nitrogen Response Surface Models of Zucchini Squash, Head Lettuce and Potato. I. Effect of $\mathrm{N}$ on Growth, Dry Matter Partitioning and on Fresh Yield and Quality. Plant and Soil 134 (2): 243-254.1991.

[9] Walworth, J. L.; Carling, D. E.; Gavlak, R., 1994. Rates and Methods of Application of Nitrogen and Phosphorus for Commercial Field Production of Head Lettuce in Southcentral Alaska. University of Alaska Fairbanks, Bulletin 100, pp 1-8.

[10] Hochmuth, G.J.; Hanlon, E.; Nagata, R.; Snyder, G.; Schueneman, T., 1994. Fertilization Recommendations for Crisphead Lettuce Grown on Organic Soils in Florida. Horticultural Sciences Department doc. SP153. Florida Cooperative Extension Service, Institute of Food and Agricultural Sciences, University of Florida. SP-153:110.

[11] Raub, L; Amrhein, C; Matsumoto, M., 2001. The Effects of Ozonated Irrigation Water on Soil Physical and Chemical Properties Ozone: Science \& Engineering 23 (1): 65-76.

[12] Norma Oficial Mexicana (NOM-001-ECOL-1996), establishing the maximum permissible limits of pollutants in discharges of wastewaters into national waters and assets. Diario Oficial de la Federación, $6^{\text {th }}$ Jan 1997. Mexico. pp 1-8. 1997. (In Spanish). 